\title{
The Need Analysis of Music Department Students to Learn English by Using the Project-Based Approach with Song Lyrics Writing as Supporting Technique
}

\author{
Penulis Prima Dona Hapsari \\ Institut Seni Indonesia Yogyakarta, email: dona.hapsari@gmail.com.
}

\begin{abstract}
The modern education system and strategies to achieve competitiveness, collaboration, and creativity are being the main focus of Indonesian higher education. They actively give positive influence to English teachers at Indonesia Institute of the Arts of Yogyakarta who particularly seek for the appropriate technique in transferring English to art students who need English as their potential engagement to the world of arts and life. For a project-based approach becomes a part of English for Special Purposes, it has been, therefore, one of the alternative approaches proposed to music students for which English is necessarily needed to accommodate their competence. The need analysis of music students would be essential to find out the appropriate techniques to teach English to art students. Therefore, the research was aimed to analyze the need analysis of music students who did the song lyrics writing as the project in English learning and to find out the significant result of implementing the project in the English class of art students of Music Department. The research used qualitative method which addressesed to descriptive analysis. The subject of this research was students of music department who were divided into six groups consisting of four to five students each, and were selectively chosen based on the purposive-sample method. The research result could be well accepted that music students produced English song lyrics and performed it as well.
\end{abstract}

Keywords: project-based approach, need analysis, song lyrics writing.

\begin{abstract}
Abstrak
Sistem pendidikan modern dan strategi untuk mencapai daya saing, kolaborasi, dan kreativitas menjadi fokus utama dari pendidikan tinggi Indonesia. Hal tersebut aktif memberikan pengaruh positif kepada para pengajar bahasa Inggris di Institut Seni Indonesia Yogyakarta yang secara khusus mencari teknik yang tepat dalam mentransfer bahasa Inggris untuk mahasiswa seni yang membutuhkan bahasa Inggris sebagai pertalian potensi mereka dengan dunia seni dan kehidupan. Karena pendekatan berbasis proyek menjadi bagian dari Bahasa Inggris untuk Tujuan Khusus, hal ini telah menjadi salah satu pendekatan alternatif yang diusulkan untuk mahasiswa musik di mana bahasa Inggris tentu diperlukan untuk mengakomodasi kompetensi mereka. Analisis kebutuhan mahasiswa musik akan menjadi penting untuk mengetahui teknik yang tepat dalam pengajaran bahasa Inggris bagi mahasiswa seni. Oleh karena itu, penelitian ini bertujuan untuk menganalisis kebutuhan mahasiswa musik yang menulis lirik lagu berbahasa Inggris sebagai proyek dalam pembelajaran menulis bahasa Inggris dan untuk mengetahui hasil yang signifikan dari pelaksanaan proyek tersebut di kelas bahasa Inggris di Jurusan Musik. Penelitian ini menggunakan metode kualitatif yang mengacu pada analisis deskriptif. Subyek penelitian ini adalah mahasiswa dari Jurusan Musik yang dibagi menjadi enam kelompok yang terdiri dari masing-masing 4-5 mahasiswa, dan secara selektif dipilih berdasarkan metode purposive sampel. Hasil penelitian ini dapat diterima dengan baik bahwa mahasiswa musik menghasilkan lirik lagu berbahasa Inggris dan juga menampilkan lagu tersebut.
\end{abstract}

Kata Kunci: pendekatan berbasis proyek, analisis kebutuhan, penulisan lirik lagu.

\section{Introduction}

Modern education systems and strategies to achieve competitiveness, colla- boration, and creativity have become the main focus of higher education in Indonesia. The issues in higher education are expected 
to meet the needs of an integrated curriculum in 2013 that can produce Indonesian people who have high standards in productivity, creativity, innovative, and affective through strengthening the integrated attitude in behavior, relevant skills, and knowledge. Problems on strengthening the quality of higher education standards can be a good way to meet the criteria of being a reputable international university. However, the academic challenges may also be a positive effect on this problem.

English teachers at the Faculty of Performing Arts, Indonesia Institute of the Arts of Yogyakarta (ISI Yogyakarta) passionately find out the appropriate learning technique for transferring knowledge and understanding the English language to arts students who need English as a medium for increasing their academic potential skills in the art world and supporting their careers as artists, academicians, and cultural workers in the future.

According to Brown (2001: 122-123), teaching English curriculum which is held in an institution of higher education refers to the contexts that are tailored to the needs of learners. There are six kinds of language curriculum which are designed to follow the different objectives of the learners, namely:

1. Pre-Academic Program, which is designed for students who prepare for the regular program at the college level.

2. EAP (English for Academic Purposes), which is a program that is widely applied to any subject, learning modules, or training where learners are academically taught the language materials and sciences associated with them.

3. ESP (English for Specific Purposes), a program dedicated to the study of science in professional fields which is in line with the academic programs of the university.

4. Vocational and Technical English, is the target of English language learning for learners who are engaged in trades, arts, and other jobs and for which are not present in the academic program of the college.

5. Literacy Program, a program designed to teach students who have low reading and writing skills.

6. Social curriculum, a curriculum that bridges the needs of learners to be able to adapt to a different culture and language of their culture, which is composed of matter of speech and language proficiency for surviving in a strange place.

From the previous description of some kinds of English curriculum, ESP is the right language curriculum for art students at ISI Yogyakarta because the student's need is to achieve scientific knowledge of the arts professionally.

In the process of analyzing and evaluating the appropriate methods for art students, a project-based approach, which becomes a part of English for Specific Purposes, namely as a method of projectbased learning approach can be applied in foreign language classes. Projects in English language learning may provide many opportunities for art students to be actively involved in the use of language in an authentic manner. In addition, they are also required to use their English skills when working and presenting the results of a project that have been done. Therefore, a project-based approach becomes an alternative method for teaching English in the art colleges. 
As an effort to improve and strengthen the English language competence, a project-based approach is proposed which may actively support the teaching and learning process in the Music Department, Faculty of Performing Arts. This can help the students of Music Department to be more active in implementing theability to write, speak, read, and listen. Doing the observation in the English class of Music Department, the average students have already been in the intermediate level, but some of them are passive learners in the classroom. Particularly, the level of students' English competence is mixed either in beginner, intermediate, or advanced level. The English teachers do not emphasize the teachercentered method, but the students-centered. The strength of students-centered method lies on the center of attention of the learning activity that is the students themselves, not the instructor. However, the success of the learning process can be measured by involving students in all forms of activity for both inside and outside the classroom. Therefore, the role of teachers is needed so that students of Music Department have awareness and sensitivity to the process of achieving the English learning in which they are required to be active learners in applying this knowledge of foreign languages.

In applying the method of projectbased approach, the English teacher puts on three basic things of the art students' needs for English, i.e. expectations, strategies, and achievement. To extend these three bacic needs, the English teacher should study the analysis of their needs for English. Students must firstly understand their needs by having a more complete learning ability and learning materials that support their learning English, such as doing the individual tasks/projects independently or in a group, accessing the Internet independently, and studying more literatures.
In this study, the researcher who is also the English teacher of Music Department emphasizes on a certain hope to increase the ability of students English writing in the Music Department, especially with the norm reference that being the art students who study arts and have highly average of the ability in music give more opportunities for the teacher in exploring and developing any English teaching and learning techniques applied in the English class. From this basic understanding, this research is considered to represent the needs of English language teachers and art students of the Music Department to learn the approach method of English writing which is interesting and challenging by writing the English song lyrics so as to strengthen their English writing skills by involving the processing of vocabulary and grammar ability at the same time.

Based on the previous description, there are two main problems which are examined by this study, as follows: (1) What are the art students' needs of English? (2) What is the significant result of implementing the project in the English class of art students of Music Department?

\section{Discussion}

\section{Teaching English as a Foreign Language}

Teaching English in foreign language classes for art students requires several approaches and methods to be applied. This is related to the teachers who have a better understanding of the students' needs on searching for and selecting the approach and methods which are most suitable to be applied in the classroom. Although in the era of post-modernism the teacher as the main role of the learning-teaching is currently not obsolute, the teachers still can be a facilitator for students. However, teachers must be committed to the success of teaching and learning English so that either the expected 
results and the objectives of the learning process itself can be achieved well.

Students of Music Department have been familiar to do some English projects in which they are encouraged to perform their English ability and competence through more interesting activities, such as: watching discography and autobiography of talented musicians, Internationally or Nationally reputable ones; analyzing the English song lyrics, interviewing artists or music experts, making the documentary movie on traditional issues, etc. By doing so, they are enthusiastic to learn and use English for their active communication and personal relationship with others. Increasing their English competence and performance are challenging yet also arousing more awareness that any techniques and approaches would be highly expected to be implemented.

The English teachers of art students at Performing Arts Faculty are supposed to have broaden understanding to see the real applied condition and situation where English is required to fulfil the students' academic achievement and the dinamic changes of globalization era. Considering the fact that the English teachers are being the great academic messenger to successful implementation of English lesson, there are three basic functions of teaching that can be applied in English language classes for students of art as stated by Burden and Byrd (2010: 10), namely:

\section{a. Planning}

Planning involves decisions about the needs of students and teachers, the most appropriate purposes and objectives, contents to be taught, learning strategies, delivery technique lessons, instructional media, classroom climate, and student assessment. It usually will be decided before the process of teaching and learning take place. Therefore, teachers should be able to choose the materials and methods that can be used for the purpose of learning so that the expected results can be achieved. Teachers should also be ready with a topic which is discussed and could affect the understanding of English and culture.

English teacher of Music Department tries to find out the appropriate teachinglearning method involving the students' participation in class. Some sequences of lesson plans which are determined by looking at the students' needs make the process of learning easier. There are some basic problems faced by the English teacher for some students are in beginner level of English and they need more supports and encouragement. It becomes the teacher consideration to find suitable techniques and make the learning activities for which the lower level students can be more active and participate in the learning process.

\section{b. Implementation}

Executing the implementation plan actually involves learning about the delivery and assessment techniques. Activities that support teaching and languageskills are implemented in the English class including the presentation and explaination, questioning, listening, monitoring, providing feedback, and demonstrating. By doing so, teachers can actively monitor the students' achievement, learning process, learners, the behavior of learners, and significant changes to the purpose of learners in learning English.

Music Department students' English mastery need to be developed for they need English as their active supports to communicate with overseas partners and to get the International links as musicians. The English teacher at Music Department provides some challenging activities to be implemented in class or outside the class. The students participate the activities well and sometimes 
get more benefits and good results of the projects given by the teacher. The given projects provide more opportunities for students to be actively involved in the learning process. Group presentation and individual or group projects become occasionally learning activities in class. The teacher can analyze that most of the students are encouraged to participate although some of the students' English competence are in beginner level.

\section{c. Assessing}

Assessing involves determining the learning level of students. Many aspects of assessment are determined during the planning phase when instructional objectives and content are identified. By providing assessment, students' achievements can be measured, and the teacher's hopes on the success of the learning process can be seen. In English, the assessment may include written tests, write a song composition, oral presentation of simple research, as well as the discussion.

Almost in every meeting, the English teacher gives the assesment to measure students' weekly achievement, from the simple to the more complicated tasks or projects given to students. It is not as easy as the teacher expects that most of the students get the point of English learning topic in every meeting. As it is well understood that English is only a part of the supporting subject for art students at art collages and given for one semester only. It is then the researcher's challenge formaking the appropriate methods which is in accordance with the art colleges curriculum.

\section{Project-Based Approach}

Project-Based approach is most often carried out in foreign language classes. This approach provides more opportunities for students to engage directly with the authentic language. According to Stoller in Richards and Renandya (2002: 109), a project-based approach is a vehicle for the English teaching as a whole and integrated, where it also assists teachers in implementing the patterns of English teaching in general, EAP (English for Academic Purposes), ESP (English for Specific Purposes), and English for Job, Vocational, and Professional Purposes.

There are several different views within this project-based approach (in Richards and Renandya Stoller, 2002: 110), namely:

a. Project-based work focuses on learning rather than the target language in particular,

b. A project-based work is a student-centered, where all activities are learner-centered although the main role of teacher here is as a provider of support and guidance,

c. A project-based work is more collaborative than the competition,

d. A project-based work motivates the integrated authentic capabilities and processes information from many sources and diverse assignments,

e. A project-based work refers more to the final outcome or the final process where the value of the project assignment lies on the final result, but still in the framework of the making process of the project itself,

f. A project-based work is potentially able to motivate, stimulate, empower, and challenge where it leads to the 
results of building the learners' confidence, selfesteem, and self-reliance.

After seeing the reference of the project-based approach, the application of this approach can be applied to the provision of independent tasks or groups in English classes for art students, especially students majoring in music.

Students can engage actively to the learning atmosphere where a project-based approach applied in the English class. For the art students need to be more independent lerners and get involved in active communication as musicians or art workers, therefore, the English teacher should find some projects which can be done in groups or individually.

\section{Methods of Teaching English Writing}

The song lyrics writing is one of the proposed techniques of English learning activities applied in the English classroom of Music Department. As the faciltitator of the English class, the teacher has been looking at the students' competence and mastery. By considering the level of English competence of Music students, the teacher also takes proposed ideas by Sokolik as the points to set the project of song lyrics writing implemented in the English class. Sokolik in Nunan (2003: 92-95) states some principles in the teaching of writing that can be adapted to the different learning atmosphere, namely:

a. Understand the reasons of learners to write.

Here, a teacher and learners should have an understanding which is in line with the objectives of the school curriculum and teaching institutions, and the teacher must be able to convey the purpose of learning to the learners.
For the project of English song lyrics writing is a part of the learning purpose of achieving English mastery for music students, then it is supposed to accommodate the need of applying vocabulary, grammar, and writing skills of music students. They completely understand that by doing the project, their English competence might be developed or increasing. The teacher gives more freedom for students to explore their critical thinking and ideas by making English song- lyrics.

b. Provide many opportunities for learners to write.

Writing skills always increase by more frequent practices. Therefore, teachers should provide a wide range of diverse writing activities in class.

The English teacher at Music Department frequently gives some topics to be discussed in class before they come into the writing part. Sometimes, the students do not get the points for they need further information and explanation regarding the topics which are unfamiliar with them. It becomes the teacher self-awareness to always bring the up-to-date phenomena or issues in relations with their major as musicians and young people into discussion.

c. Give helpful and meaningful feedback.

Learners need any feedback or assessment of their writing, although it does not always give the intended effects. Teachers must have the extra time to discuss with students in the classroom.

Frustrating and lack of interest may occur during the process of writing. Therefore, the English teacher provides some guidances to assist the students in writing the targeted topic to be explored. In the English class of Music Department with mixed level of students' competence, the teacher gives 
feedback after they finish with their writing by doing the self-approach to those who produce more language errors. Meanwhile, for those who perform well, the teacher gives appreciation to invite them coming to the front of the class to write their writing assessment or results.

d. Explain yourself and students how their writing will be evaluated and assessed clearly.

Avoid subjective assessment to avoid statements which are not expected from learners. The teacher can provide a systematic assessment of transparent and systematic for learners as a material to develop the content and ideas of their writing.

The English topic to be developed into writing project encourages students to compose more writing ability in class. By the time the teacher gives the task or project, she also needs to explain clearly with the standart of the evaluation and clear puposes of writing. Sometimes, the students do not meet with the teacher's expectation in composing sentences or making paragraphs, however, the teacher and students get more values in communicating the project, applying the language skill, and exploring their ideas freely.

In English teaching, there are several techniques that can be used and applied by teachers in accordance with the syllabus design and the ultimate goal of teaching and learning process. In this situation where English song lyrics writing is accomodated to suitably learning activities for students, the teacher tries to figure out what Kroll in Murcia (2001: 224) suggest for the techniques of teaching writing in a language class which are found as follows:

a. Brainstorming, which is a technique of exercise in which the learners in the class are encouraged to play an active role in sharing knowledge about a certain topic.

b. Listing, which is a technique that is different from the brainstorming exercise, where it tends to emphasize the individual activity. The learners are encouraged to generate lists as much as possible of the main ideas and sub-categories of their thinking.

c. Clustering, which is another exercise technique to generate as many ideas as possible starting with the keywords or key ideas which are placed in the middle of the page, and uses many words and short phrases.

d. Freewriting, which is a technique of writing exercise which helps foreign speakers to overcome the difficulties of starting the writing exercise freely. In teaching English as a foreign language, this technique is the best when teachers provide the guiding or opening sentence for learners.

The suggested techniques of writing then are formulated by the teacher to be applied in the class. Free writing combined with brainstorming is commonly used in teaching English writing at Music Department. Some basic considerations why the free writing and brainstorming activity are suitable for art students are taken during the process of need analysis of students in learning English. Free writing which is combined with brainstorming may influence students to draw their concept of thinking while they try to figure out the topic to explore into writing. Providing more challenging topics referring to peforming arts is then applied to music students in composing short paragraphs or exposition. Language errors made during the learning activity become the teacher's attention in which she needs to discuss them with students and give feedbacks soon they revise 
them. However, the most important part of this activity is that students can expandly explore the topic based on their critical thinking and points of view in developing the topic into paragraphs. The result of this project lies on how they can explore the topic into interesting paragraphs.

In giving the writing assignments for students, a teacher should consider the guidelines for successful writing assignments (Kroll in Murcia, 2001: 226), they are as follows:

a. The task of writing should be given by clear context in which learners can understand the tasks assigned to them.

b. The content of the material or topic of writing can be accessed by the author and could be directed at many of the approaches used.

c. The language used in the task of writing must be appropriate, clear, and understandable.

d. The assignment given to students should focus on the completion of time or duration in a timely manner, and must comply with the average ability of the learners in each language class.

e. The assignment instructions must be focused and clear, that is about the information of the form and format of writing including the writing reference.

After seeing the techniques of teaching writing, the most appropriate one to be applied in class is freewriting which is integrated with other components of the language in English classes for art students. In addition, English teacher in music department can provide the appropriate steps in the provision of English writing assignments in class. Particularly, in the provision of song lyrics writing project, the researcher can apply the principles of teaching writing and refer to the guidelines of giving song lyrics writing project in the English class. It is hoped that the process and the final result of the assignment can be seen and analyzed to provide various teaching methods and be good for the development of English language proficiency of students majoring in music.

\section{Research Methodology}

This study used a qualitative method with descriptive analysis. This method is the most suitable one in this study because the qualitative method is easier when the researcher encounters a double reality, serves directly the nature of the relationship between researcher and respondents, and more able to adjust to many influences together and to patterns of values encountered (Hikmat, 2011: 38). In analyzing the song lyrics writing in the teaching of English writing, the researcher used a subjective approach.

The samples of this study were students of music who took an English subject. The sampling technique used was "non-random sampling", i.e. not all individuals in the population are given the same opportunities to set up as members of the sample. Therefore, the type of samples in this study were taking "purposive sample" or the aimed sample. (Moleong, 1997: 165). This is because the sampling is based on the characteristics or specific traits that are considered to have a close relation with the population, necessarily for the object of this research that is students of music department.

This study used some instruments, such as student assignment sheets, photos and videos, questionnaires, as well as the CDaudio recorded music as the project results. Meanwhile, for the research implementation, 
the qualitative data was obtained by doing the followings:

a. The observation of music students who joined the English class, especially during the process of writing project;

b. The distribution of questionnaires to students majoring in music following the English class in even semester period 2015. The researcher provided the detailed questions of the issues raised in this study. Respondents in this study consisted of thirty students which were divided into six groups and were considered as the representative of the population.

c. The video recording and taking photographs of student activities during the writing project in the classroom.

d. The collection of student writing project from the beginning to the end of the class period and then provided feedback to the students to obtain the expected results.

The object of this study was the result of writing project of students majoring in music who joined the English lecture and at the end of the project they gave the result of musical compositions and song lyrics in English. The result of the study was the songwriting project done in groups of thirty students consisting four to five students per each. While the subject of this study was the Music Department students who took the English subject in the even semester period of 2015.

In this study, the researcher carried out the data collection method that was a method used to obtain the data to answer the problem formulation. In this case, the method selected must be fit and have a strong reason to use. Library Study was carried to search for the related literature to support the findings and the theoretical review. The observation and interview technique were used to see, observe, and record any information from the sources and object of research, allowing the researcher notes that the situation with regards to knowledge which is obtained directly from the data. In this study, the researcher conducted observations in the English class. Interview and distributing questionnaire techniques which were also combined with the observation technique were useful to determine the acceptance and understanding of the students in implementating the song lyrics writing project. The researcher also documented the sheets of song lyrics writing project from the beginning to the end in the form of their original works in the format of a song with the musical composition.

\section{Data Analysis}

The analysis technique of this research was descriptive analysis. After the observation, the distribution of questionnaire, and interview, the researcher then carried out the data analysis which was then used as a guidance in answering the questions proposed in this study.

The data analysis process was done through several stages. The first stage was to identify, collect, and select the relevant data with the object and subject of research, so that the data presented was in accordance with the subject of the issues raised in this study. The data analyzed was based on the results of the literature study; observation, which includes the distribution of questionnaires; taking pictures and recording activities in the classroom, and the results of student's project. These four things were then processed into data which were analyzed and evaluated as the basis and reference for answering the problems proposed in this study. The final data analysis stage was to 
present the data in accordance with the needs of researcher in interpreting the results of the research and as the reference of researcher in designing the instructional materials for teaching English writing.

The English teacher provided clear and understanable instruction of project. Since the beginning of the meeting, she always discussed all possible things which might occur during the project implementation. This was clearly used to minimize the lack of information occurred and to maximally obtain the students's focus in applying their English writing skill. For the focus was the exploration of vocabulary and grammar skills, the teacher suggested them to carefully emphasize on their productive sentences which were always discussed in each meeting for formulazing the final productive result of English song. Though it was not easy to implement it, there was a mutual understanding between the teacher and students, especially those who did not have sufficient mastery in English. Their effort was being appreciated and it was the teacher who gave them points to be revised and clarified the mistakes of grammar or vocabulary products to be well acknowledged. Each meeting was supportly accomodated by each group to compose good English sentences referring to English song project.

Through several meetings of discussion and revision, the final outcomes of the project were finalized. The students were impressed and enthusiastics toward the project. The impacts and contributive learning outcomes were seen through the song lyrics and performance of each group. All neglecful points before the project was done seemed to be awared by the students. Those then were made into analysis of the the students' needs.

The findings of the study address to the following discussion based on the data reviews of thirty students as the research subjects and research results. They are as follows:

a. The needs of the art students to learn English were taken from the interview and questionnaire. They can be concluded as follows:

1) English is important for it is widely used all around the globe. By having good English we can convey sort of activities related to buiding networks and sharing ideas with others as well.

2) English is as one of the most important means of communication. By having good English, students get more opportunities to develop their talents and expertise.

3) Students are expected to master the English language because they must acquire more vocabulary and English literature in developing their critical thinking as students.

4) Music students need to learn English for easier communication with overseas people/foreigners who come to Indonesia, specifically. By learning western music, they automatically welcome any cooperation and partnership with those English native speakers.

5) English becomes one of main important elements to study abroad.

6) Learning English for Music students is said to be very important since it is the international language. The art workers and expertise in arts are easier to get more opportunities to 
develop their potentials around the globe.

7) Music is widely developed in the universe and it becomes wellaccepted by all people from different genre, age, and countries. Therefore, English makes the process of communication and learning much easier.

8) As musicians and art workers, English is very much needed especially for students to broaden and strengthen their knowledge and understanding in music.

9) English does not merely become one of the international languages so that to face the twentieth century development, the music students must acquire the language, especially English as the major language to master and as the potential skill to struggle for music understanding globally and broadenly.

10) English is necessary to be used in music learning since there are many things concerning to music literatures and its development. By knowing English, reading the books and English literatures are much easier and helpful.

b. The significant results of implementing the project in the English class of art students of Music Department are the followings:

1) The project-based approach is a part of English teaching writing methodology which is actively able to support the process of teaching-learning at Music Department.
2) The given project to music students at the English class can give them many opportunities to get actively involved in applying the language authentically.

3) Freewriting and brainstorming are two writing assessment techniques to support students at Music Department overcoming any obstacles in starting the writing project or tasks freely, especially in writing the English song lyrics.

4) The English project in writing English song lyrics and composing the music can help students become active learners to implement and practice the language abilities, such as writing, reading, listening, and vocabulary.

5) The English writing which is interesting and challenging in the form of writing the English song lyrics can strengthen the students' writing skill by involving the ability of vocabulary development and English grammar at the same time.

6) The English teacher actively supports cooperative learning by guiding students to share their competence, minimize negative competition among students, enhance students to consider themselves as a team and more to work in groups.

7) The teacher is able to support and increase students' writing ability which is accordance with students' needs and English curriculum for arts students. 
The English teaching-learning method must be applied in the English class of Music Department by more focusing on active learning, various techiniques and methods based on students' needs and art curriculum, various learning activities based on students' level of competency, and learner-centered basis.

\section{Conclusion}

The project of English song lyrics writing implemented in the English class of Music Department students has been regarded successful when they students have successful followed the stages of processing the English writing technique. The proposed technique is in accordance with the needs of students to acquire English. As the projectbased approach is a part of English for Specific Purposes applied in the English class of art students, then a certain technique in teaching writing has been set up to the highly configuration of students' English mastery. English song lyrics writing becomes one of the writing techniques implemented in the English class of music students. By doing the final stage of composing a song along with the music compositition, the needs analysis of students of the Music Department are formulated. Therefore, it may be concluded that the project-based approach with the song lyrics writing is done successfully yet also need to be developed more in obtaining the more language acquisition of students.

\section{Reference}

Brown, H.D., 2002. "English Language Teaching in the 'Post-Method' Era: Toward Better Diagnosis, Treatment, and Assessment" in Richards and Renandya, Methodology in Language Teaching: An Anthology of Current
Practice. New York: Cambridge University Press, pp. 9-17.

Burden, P.R. dan Byrd, D.M., 2010. Methods for Effective Teaching: Meeting the Needs of All Students, 5th ed. Boston: Allyn\&Bacon.

Hikmat M. Mahi, 2011. Metode PenelitianDalam Perspektif Ilmu Komunikasi dan Sastra. Yogyakarta: Graha Ilmu.

Kroll, Barbara, 2001. "Considerations for Teaching an ESL/EFLWriting Course" in Murcia, Marianne Celce, Teaching English as a Second or Foreign Language, 3rd Edition. Boston: Thomson Learning, Inc., pp. 224.

Moleong, Lexy J, 1997. Metodologi Penelitian Kualitatif. Bandung: PT. Remaja Rosdakarya.

Sokolik, Maggie, 2003. "Writing" in Nunan, David, Pratical Language Teaching. New York: Mc Graw-Hill, Inc., pp. 9497.

Stoller, Fredricka L., 2002. “Project Work: A Means to Promote Language and Content" in Richards and Renandya, Methodology in Language Teaching: An Anthology of Current Practice. New York: Cambridge University Press, pp. 109-110. 